\title{
Pollination of English Walnuts: Practices and Problems
}

\author{
William H . Krueger
}

AdDitional INDEX WORDS. Juglans regia, Juglansnigra, pollination, monoecious, dichogamous, wind-pollinated, pistillate flower abortion.

Summary. English walnut (J uglans regia, L.) is a monoecious species bearing staminate and pistillate flowers separately on the same tree. Walnuts are generally self-fruitful, cross-compatible and dichogamous, having incomplete overlap of pollen shed and female receptivity. It is this characteristic which led to the recommendation that about $10 \%$ of the trees in a commercial planting be a cultivar with a pollen shed period overlapping pistillate flower receptivity of the main cultivar. Excessive pollen load has been implicated in the 'Serr' cultivar in pistillate flower abortion (PFA), the loss of the female flowers early in the season before fruit drop due to lack of pollination. PFA can be reduced and yield improved in 'Serr' orchards by reducing pollen load. This can be accomplished by pollinizer removal, or catkin removal at the beginning of pollen shed by mechanical shaking. In years of significant bloom overlap between staminate and pistillate bloom, PFA can be further reduced and yield improved by removing 'Serr' catkins. PFA occurs to a lesser extent in other cultivars such as 'C hico', 'C handler', 'Vina' and 'H oward'. This information has led to the reevaluation of pollinizer recommendations. R esearch focused on optimum pollinizer levels in 'C handler', a cultivar of increasing importance to the California walnut industry, has been inconclusive. Lack of pollinizers may impact yields to a greater extent in the in the northern San Joaquin Valley and Sacramento Valley than in the southern San Joaquin Valley. In any case the previously recommended $\mathbf{1 0 \%}$ appears to be excessive. T wo to three percent is probably adequate to limit losses due to lack of pollination without resulting in excessive PFA, and is currently being recommended by extension farm advisors and specialists. Factors to consider when determining the number of pollinators to plant include: cultivar susceptibility to PFA, walnut pollen load in the area and local pollination and fruit set experiences.

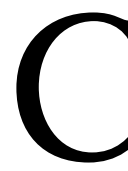

alifornia accounts for $99 \%$ of the U.S. English walnut production producing 220,000 tons $(199,600 \mathrm{t})$ of inshell walnuts on 193,000 bearing acres (78,106 ha) in 1998 (C alifornia Agricultural Statistics Service, 1998). About $90 \%$ of this production is located in the Central Valley (comprised of the Sacramento Valley to the north and the San J oaquin Valley to the south). Of this, about $50 \%$ is located in the San J oaquin Valley and 40\% is located in the Sacramento Valley. Walnuts are monoecious, (Polito, 1996) bearing staminate and pistillate flowers separately on the same tree. They are generally self fruitful and cross compatible. Typically the period of pollen shedding does not completely overlap the period of female receptivity. This is known as dichogamy. It is this characteristic which resulted in the recommendation that pollinizers with a pollen shedding period overlapping the pistillate flower receptivity of the main cultivar be included in commercial plantings (Forde and Griggs, 1975).

U niversity of California Cooperative Extension, P.O. Box 697, O rland, CA 95963.

The cost of publishing this paper was defrayed in part by the payment of page charges. U nder postal regulation, this paper therefore must be hereby marked advertisement solely to indicate this fact. 
When pollen shed occurs before female flower receptivity they are said to be protandrous. This is the most common situation for $\mathrm{C}$ alifornia cultivars. When female receptivity occurs before pollen shed, the cultivars are said to beprotogynous. Figure 1 shows the relationship between pollen shedding period and peak pistillate bloom for the most common California cultivars ( $\mathrm{H}$ endricks et al., 1996).

Staminate flowers develop on the previousseason'sgrowth and aresmall, inconspicuous and grouped together in hanging clusters known as catkins. The individual flowers lack petals and consist of a whorl of green sepals surrounding 40 pollen bearing stamens. Each stamen terminates in an anther which has numerous pollen grains.

Pistillate flowers are formed most often in pairs and develop from the terminal bud on all cultivars (terminally fruitful) and from lateral buds on certain cultivars ( laterally fruitful). Pistillate flowers begin to differentiate in the late spring or early summer of the year before bloom. The final stages of floral bud initiation occur in the weeks before bloom. The basal portion of the flower is enclosed in a hairy involucre which is formed by the fusion of flower parts including bracts and sepals (Fig. 2). This tissue eventually develops into the husk of the walnut. The enlarged basal portion of the pistil is the ovary, which eventually producesthenut. The pistil contains a relatively large two branched stigma which is connected to the ovary by a short style.

Catkins begin to elongate in the spring. As they elongate the pollen is released and dispersed by the wind. As the pistillate flower develops, the stigmas begin to separate. Cells on the stigma surface secrete a sticky exudate which catches the pollen grains and acts as a substrate for germination. Pistillateflowers are receptive for up to $7 \mathrm{~d}$ under ideal conditions. O nce the stigma lobes open to about $45^{\circ}$ they stop secreting exudate and are no longer receptive. When thepollen grain reachesthestigma (pollination), it germinates and the pollen tube penetrates between the cells on the stigma surface, grows through the style into the ovary, into the ovule and to the egg sac. It then releases two sperm. O ne fuses with the egg effecting fertilization and forming azygote. Thesecond sperm fuses with atwo-celled nuclei in the egg sac to form the endosperm which provides nutrition for the developing embryo. It is consumed by the time the nut is mature. The zygote divides 7 to $10 \mathrm{~d}$ after fertilization to begin theperiod of development which ultimately results in the development of the embryo (the kernel). Pollina- tion to fertilization takesabout 1 week. $\mathrm{N}$ umerouspollen grainsgerminateand pollen tubes grow into the style, but only onecan penetrateand fertilize the egg. U npollinated flowers will continue to grow for several weeks before they drop from the tree.

\section{Pistillate flower abortion}

Pistillate flower abortion is the loss of pistillate flowers early in the season, about 2 to 3 weeks after bloom when the flowers have reached a size of $3 / 16$ inch (4 to $5 \mathrm{~mm}$ ). PFA flowers emerge and grow normally in the spring. After the stigmas expand, growth stops and they soon become necrotic and drop. PFA occurs 2 to 3 weeks before flower drop due to lack of pollination. L osses from PFA can be particularly high in cultivars such as 'Serr' where losses have reached $90 \%$ (Polito, 1996.)

Shortly after the first commercial plantings of 'Serr' came into production in the mid 1970s, severe drop of

Fig. 1. R elationship of pollenshedding period to time of peak pistillate bloom. These data describe walnut trees growing in an orchard at the U niversity of C alifornia, Davis. $T$ he number of days cited is an average based on findings for 5 years (1986-90) (H endricks et al., 1996).

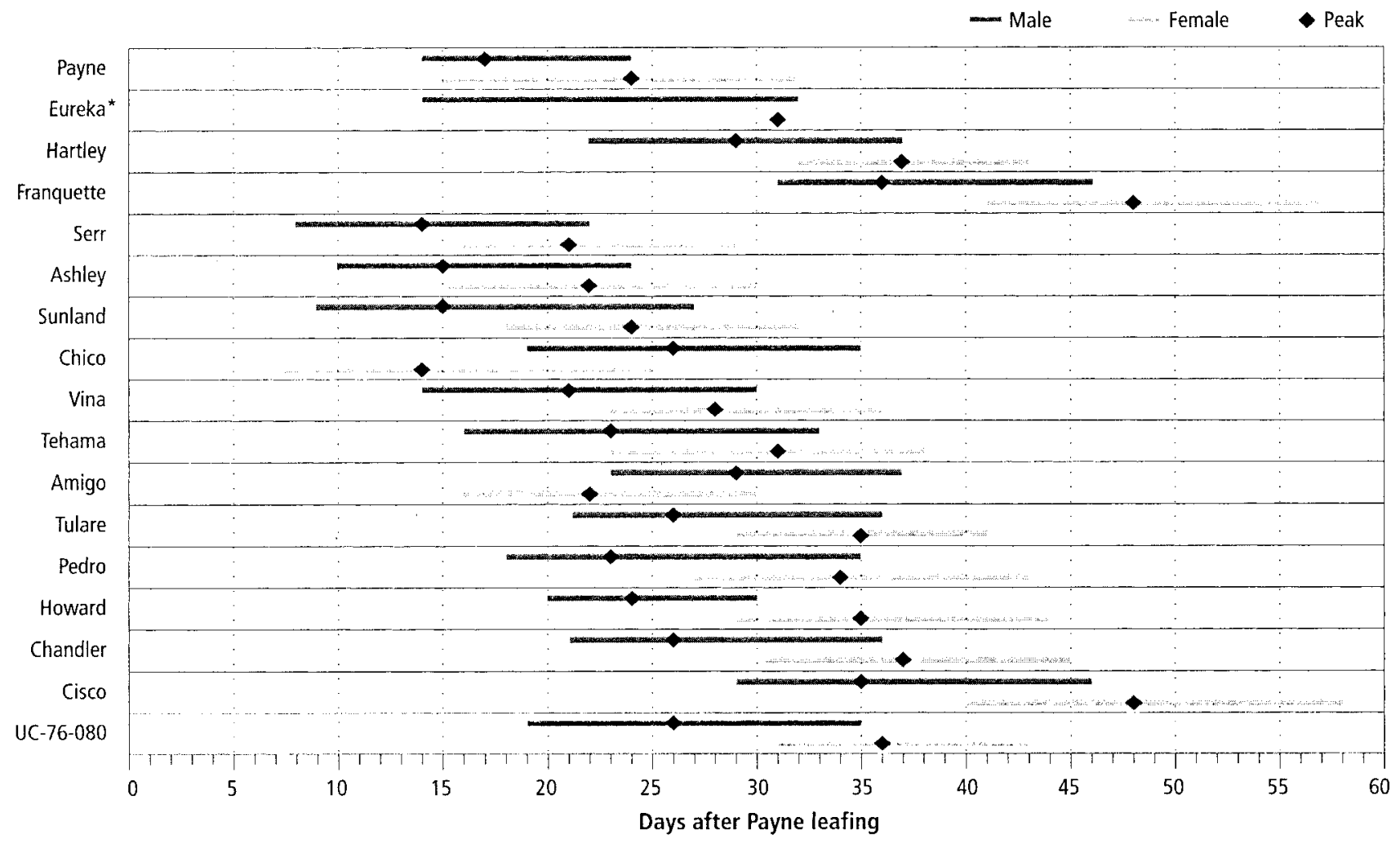




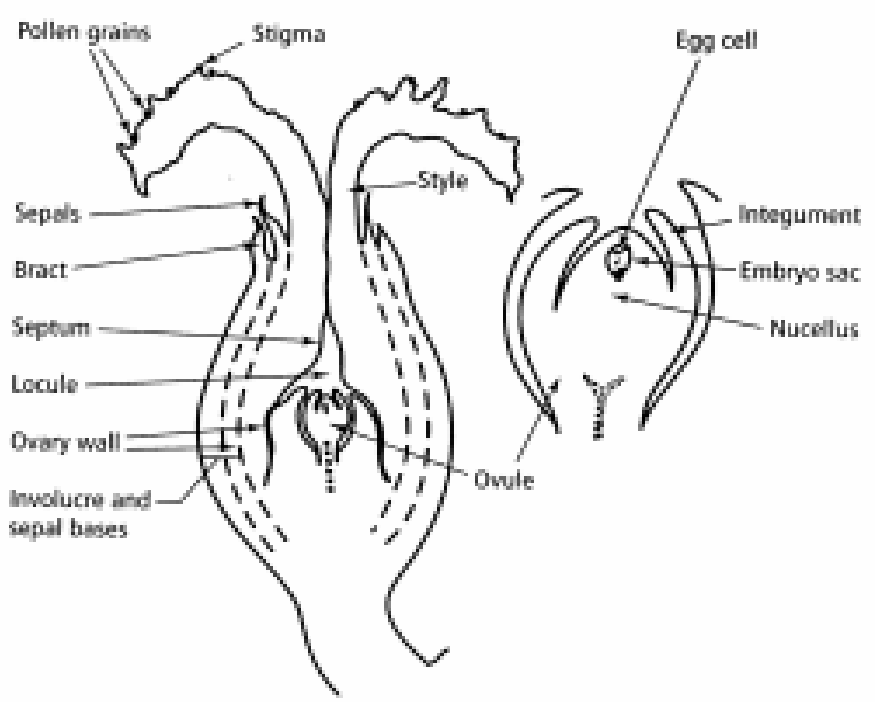

Fig. 2. L ongitudinal section of a pistillate flower (Polito, 1996).

thepistillateflowersshortly after bloom wasnoted (Polito, 1996). Research by U niversity of California (U C) during the 1980s ruled out pests and diseases, nutrient deficiencies, tree age, shading, pruning practices, and incompatible pollen or lack of pollen as possible causes (Catlin et al., 1987). During this time period, it was observed that PFA varied among sites from year to year and was not limited to the 'Serr' cultivar. In the late 1980 s and early 1990 s, U C researchers began to investigate the role of excessive pollen load in PFA. Early experiments with flowers that received high doses of pollen showed that PFA was correlated with pollen load. Walnut cultivars varied in their response to high pollen load and PFA was unrelated to pollen source (Catlin et al., 1990; M CGranahan et al., 1991).

Research conducted by Polito et al. (1996a) during the 1990s on 'Serr' has shown that: PFA is positively correlated with pollen load. Counts of pollen grains on pistillateflowers show that high PFA is al ways asso ciated with high numbers of pollen grains. D ose response curves indicated that 70 to 100 pollen grains per pistillate flower would induce PFA in $50 \%$ of the flowers. This relationship was consistent for orchards from different parts of California.

PFA is positively correlated with distance to a pollen source. The 'T ehama' cultivar has been widely used as a pollinizer for 'Serr' in California. The percentage of PFA varied from orchard to orchard and from year to year, but was alwaysgreatest next to the pollinizer row and declined with distance from the pollinizer, usually stabilizing 250 to $300 \mathrm{ft}$ (76 to 91 m) from the pollinizer. Sometimes PFA was as high as $80 \%$ adjacent to the pollinizer.

PFA reduces yield. In 'Serr' orchards yield was consistentlylower next to the pollinizer row and increased with distance from the pollinizer.

Reducing pollen load Reduces PFA AND INCREASES YIELD. In experiments where pollen load was reduced, either by pollinizer removal or by shaking catkins from the pollinizer trees before pollen dispersal, PFA was significantly reduced and yield was significantly increased compared to areas in the same orchards where catkins or pollinizers were not removed.

In experiments where 'T ehama' pollinizers were removed, PFA was reduced and yield was improved by 20 to $86 \%$ compared to where pollinizers were not removed. Response would be expected to be greatest where PFA has been chronic and or where high percentages of pollinizers had been used.

Pollen load can be reduced and yield improved by mechanically removing catkins from pollinizer trees using the same shaker harvester used for walnut harvest. In years of significant overlap of staminate and pistillate flowers, yieldscan be increased further by shaking the catkins from the 'Serr' trees. In experiments where catkins were removed from 'Tehama' pollinizersin 'Serr' orchards, PFA was reduced and yields were increased 16 to $26 \%$ compared to nonremoval of catkins. In years of extensive overlap between pollen shedding and pistillate bloom, catkin removal from both 'Serr' and 'T ehama' reduced PFA and improved yields. This increased yield by $16 \%$ compared to an area where catkinswere removed only from 'T ehama'.

For best results, catkins should be shaken when the first catkins fall from the tree. At this time pollen shed has begun, but most of the catkins are about half elongated, have not begun to shed pollen and can be removed from the tree without excessive force. $\mathrm{U} p$ to $80 \%$ of the catkins can be removed at this time by shaking. In the case of an adjacent block of pollinizers, all trees within $150 \mathrm{ft}(46 \mathrm{~m})$ of the "Serrs' should be shaken.

Pfa in other cultivars. PfA due to excess pollen load is known to occur, although to a lesser degree, in cultivars other than 'Serr' . (C atlin and O Isson, 1990). Fig 3 shows PFA relative to distance from the pollinizer in representative orchards for 'Serr', 'Vina', 'C handler' and 'C hico' (Polito et al., 1996a). PFA for 'C handler' and 'Vina' adjacent to pollinizers typically was about $40 \%$ with average PFA for the orchards between 15 and $20 \%$ 'Chico' typically showed PFA levels near the pollinizer about 20 to $25 \%$ with average PFA for the blocks being around $10 \%$. Resultsfrom experiments conducted with 'Chandler' cultivar designed to determine what levels of pollinizers would result in adequate pollination without resulting in excessive PFA were variable and inconclusive (Polito, et al., 1996b). In Tulare County in the southern San Joaquin Valley, orchards without pollinizers did have a slightly reduced set due to lack of pollination, but losses were not as great as losses due to PFA in orchards with pollinizers. Pollinizer removal was correlated to reduced PFA and increased yield. In the northern San J oaquin V alley and the Sacramento Valley, the results were less clear. In San J oaquin County in the northern San J oaquin Valley no correlation was found between distance from the pollinizer and PFA and no significant differencein yield resulted from pollen removal. In a Yolo County orchard in the southern Sacramento Valley, no correlation between distance from the pollinizer and PFA was measured. Post PFA drop, most likely due to lack of pollination was reduced by the presence of pollinizers. In three other orchards in the Sacramento Valley, in Sutter and Butte Counties, PFA was not reduced by removing catkins from pollinizers or with distance from the pollinizers. In one Butte County orchard, slight increases in yield were detected with increasing distancesfrom pollen sources, indicating that the method of analysis may have been 
insufficient to provide a complete picture of PFA throughout the orchard canopy. Thismay haveunderestimated PFA in 'C handler' orchards.

These results make it difficult to generalize regarding the effect of pollinizers on PFA in 'Chandler'. H owever, there does appear to be greater need for pollinizersin thenorthern San J oaquin and Sacramento Valleys than in the southern San J oaquin Valley. Theneed for pollinizersisprobably greater in areas of limited walnut plantings.

\section{Current pollinizer recommendations}

In the past some growers have supplemented natural pollination with aerial application of supplemental pollen. Pollen infected with the walnut strain of the cherry leaf roll virus has been shown to spread walnut blackline disease, a serious disease of english walnut in California which limits production in some areas and threatensto increase in incidence in others (M ircetich et al., 1996.) The virus entersthetreethrough infected pollen and travels slowly through the english scion, a symptomless carrier. Most english walnuts in Californiaaregrown either on northern california black (Juglans hindsi Jepson) or Paradox hybrid (J uglensregia x J uglanshindsi i) rootstock. When the virus arrives at thegraft union, the first cellsare killed, forming a black line, girdling the tree and leading to decline and eventual tree death. Trees may be infected for many years before the symptoms appear, and there are no practical means

\section{Fig. 3. Pistillate flower abortion} (PFA) in representative orchards of 'Serr', 'Vina', 'C handler', and 'C hico' as a function of distance from the pollinizer (in parentheses) (Polito et al., 1996a); $10 \mathrm{ft}=3.0 \mathrm{~m}$.

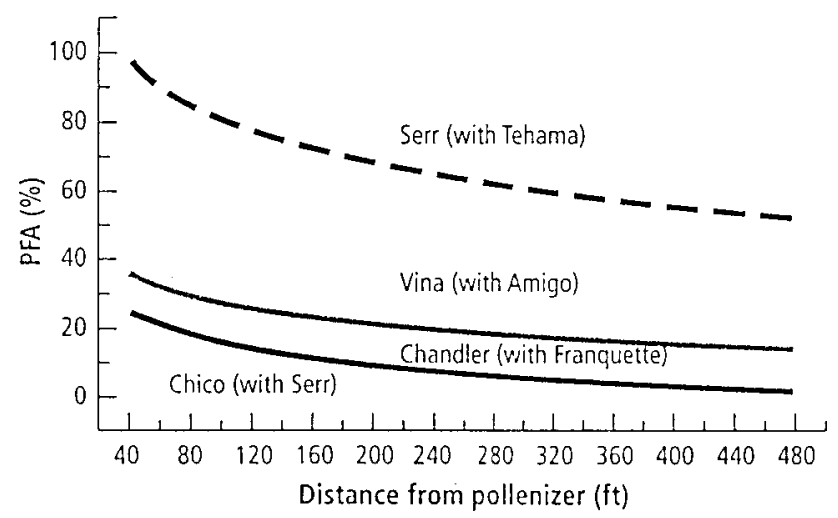

of determining if pollen is infected. Therefore, the practice is of questionable value and is not recommended.

Pollen isrequired for crop set, but the necessity and density of pollinizers is unclear. The long standing recommendation had been that about 10\%of the trees in a planting be of a cultivar with a good overlap of the staminate bloom with the pistillate bloom of the main cultivar (Fordeand G riggs 1975.) For ease of harvest, the pollinizers were usually placed in complete rows starting with the first row on the upwind side of the orchard. This level of pollinizers is almost certainly more than required to set the crop and may contribute to crop loss from PFA.

Factors that should beconsidered when considering pollination requirements for a new orchard follow.

Coincidence between the stamiNATE AND PISTILLATE BLOOM ON THE CULTIVAR BEING PLANTED. If all but earliest or latest pistillateflowerscoincide with pollen release, it is unlikely that a pollinizer is necessary.

Cultivar susceptibility to pFa. PFA susceptibility varies with cultivars. For a cultivar such as 'Serr', which is highly susceptible, the risk of crop loss due to PFA is probably greater than the potential loss due to lack of pollination. With a less susceptible cultivar, the pros and consof asmall number of pollinizers should be considered.

WALNUT DENSITY IN THE AREA. Walnut pollen iswind borne. I $n$ areas where walnut plantings are common, there maybelargeamounts of pollen in the air during walnut bloom. This may be adequate or may require the addition of a small number of additional pollinizers to insure adequate pollination.

\section{Local experience with walnut pollination}

As has been noted, the need for pollinizers may vary depending on location. In the southern San Joaquin Valley, 'Chandler' losses due to PFA were generally greater than were losses due to lack of pollination. Thisgenerally was not the case in the northern San Joaquin and Sacramento Valleys, where it was difficult to correlate PFA with dis- tance from the pollinizer row, but drop due to lack of pollination was sometimes noted.

In general, recommendations for pollinizers have been reduced in recent years and are currently between 2 and $3 \%$ pollinizers depending on the factors listed above.

\section{Literature cited}

California Agricultural Statistics Service. 1998. California walnut acreage survey. C alif. D ept. Food Agr., Sacramento.

Catlin, P.B. , D.E. Ramos, G.S. Sibbett, and W.H. OIson. 1987. Pistillate flower abscission of the persian walnut. $\mathrm{H}$ ortScience 22:201-295

Catlin, P.B. and E.A. O Isson. 1990. Pistillate flower abcission of walnut-'Serr', 'Sunland', 'H oward' and 'C handler'. H ortScience 25:1391-1392.

Catlin, P.B., G. MCGranahan and D. Voyatzis. 1990. Pistillate flower abscission. Wal nut M ktg. Board Res. Rpt. Calif. Walnut Comm., Sacramento.

Forde, H .I., and W.H . Griggs. 1975. Pollination and blooming habits of walnuts. U niv. Calif. Div. Agr. Sci. Lflt. 2753.

H endricks, L.C., W.W. Coates, R.B. Elkins, G.H. M cGranahan, H.A. Phillips, D.E. Ramos, W.O. Reil, and R.G. Snyder. 1996. Selection of varieties, p. 84-89. In: D.E. Ramos (ed.). Walnut production manual. U niv. Calif. Div. Agr. N atural Resources Publ. 3373.

M ircetich, S.M ., A. R owhani, E.L. Civerelo, and D.E. Ramos. 1996. Blackline disease, p. 233-241. In: D.E. Ramos(ed.). Walnut production manual. U niv. Calif. Div. Agr. N atural Resources Publ. 3373.

M CG ranahan G., P. Catlin, V. Polito, S. Sibbett, K. K elly, L. H endricks, J. Grant, J. Luza, and R. Synder. 1991. Pollen and pistillate flower abscission, p. 65-71. In: 1991 Walnut M ktg. Board Res. Rpt.

Polito, V.S. 1996. Floral biology: Structure, development and pollination, p.-127-132. In: D.E. Ramos(ed.). Walnut production manual. U niv. Calif. Div. Agr. N atural Resources Publ. 3373.

Polito, V.S., G.S. Sibbett, J.A. G rant, K.M . Kelley, and P.B. Catlin. 1996a. Pistillate flower abortion and pollination management, p. 133-138. In: D.E. Ramos (ed.). Walnut production manual. U niv. Calif. Div. Agr. N atural Resources Publ. 3373.

Polito, V.S., B. Coates, J. Grant, J. H asey, W. M icke, B. O Ison, and K. Pinney. 1996b. Pollen, pistillate flower abortion/ abscission, p. 77-87. In: 1996 Walnut M ktg. Board Res. Rpt. 